\title{
Article
}

\section{Impacts of Repeated Redox Cycling on Technetium Mobility in the Environment}

Masters-Waage, Nicholas K., Morris, Katherine, Lloyd, Jonathan R., Shaw, Samuel, Mosselmans, J. Frederick W., Boothman, Christopher, Bots, Pieter, Rizoulis, Athanasios, Livens, Francis R. and Law, Gareth T. W.

Available at https://clok.uclan.ac.uk/21678/

Masters-Waage, Nicholas K., Morris, Katherine, Lloyd, Jonathan R., Shaw, Samuel, Mosselmans, J. Frederick W., Boothman, Christopher, Bots, Pieter, Rizoulis, Athanasios orcid iconORCID: 0000-0002-5540-1691, Livens, Francis $R$. et al (2017) Impacts of Repeated Redox Cycling on Technetium Mobility in the Environment. Environmental Science \& Technology, 51 (24). pp. 1430114310. ISSN 0013-936X

It is advisable to refer to the publisher's version if you intend to cite from the work. http://dx.doi.org/10.1021/acs.est.7b02426

For more information about UCLan's research in this area go to http://www.uclan.ac.uk/researchgroups/ and search for <name of research Group>.

For information about Research generally at UCLan please go to http://www.uclan.ac.uk/research/

All outputs in CLoK are protected by Intellectual Property Rights law, including Copyright law. Copyright, IPR and Moral Rights for the works on this site are retained by the individual authors and/or other copyright owners. Terms and conditions for use of this material are defined in the policies page. 


\section{Impacts of Repeated Redox Cycling on Technetium Mobility in the Environment}

Nicholas K. Masters-Waage, ${ }^{\dagger, \ddagger}$ Katherine Morris, ${ }^{\ddagger}$ Jonathan R. Lloyd ${ }^{\ddagger}$ Samuel Shaw, ${ }^{\ddagger}$ J. Frederick W. Mosselmans, ${ }^{\S}$ Christopher Boothman, ${ }^{\ddagger}$ Pieter Bots, ${ }^{\ddagger}, \|$ Athanasios Rizoulis, ${ }^{\ddagger} \perp$ Francis R. Livens, ${ }^{\dagger}$ and Gareth T. W. Law ${ }^{*}{ }^{\dagger}$ (i)

${ }^{\dagger}$ Centre for Radiochemistry Research, School of Chemistry, The University of Manchester, M13 9PL, Manchester, United Kingdom

${ }^{\ddagger}$ Research Centre for Radwaste Disposal and Williamson Research Centre, School of Earth and Environmental Sciences, The University of Manchester, M13 9PL, Manchester, United Kingdom

${ }^{\S}$ Diamond Light Source Ltd., Diamond House, Harwell Science and Innovation Campus, Didcot, Oxfordshire, OX11 0DE, United Kingdom

\section{Supporting Information}

ABSTRACT: Technetium is a problematic contaminant at nuclear sites and little is known about how repeated microbiologically mediated redox cycling impacts its fate in the environment. We explore this question in sediments representative of the Sellafield Ltd. site, UK, over multiple reduction and oxidation cycles spanning $\sim 1.5$ years. We found the amount of Tc remobilised from the sediment into solution significantly decreased after repeated redox cycles. X-ray Absorption Spectroscopy (XAS) confirmed that sediment bound $\mathrm{Tc}$ was present as hydrous $\mathrm{TcO}_{2}$-like chains throughout experimentation and that Tc's increased resistance to remobilization (via reoxidation to soluble $\mathrm{TcO}_{4}{ }^{-}$) resulted from both shortening of $\mathrm{TcO}_{2}$ chains during redox cycling and association of $\mathrm{Tc}(\mathrm{IV})$ with $\mathrm{Fe}$ phases in the sediment. We also observed that $\mathrm{Tc}(\mathrm{IV})$ remaining in solution during bioreduction was likely associated with colloidal magnetite nanoparticles. These findings highlight crucial links between Tc and Fe biogeochemical cycles that have significant implications for Tc's long-term environmental mobility, especially under ephemeral redox conditions.

\section{INTRODUCTION}

The geological disposal of radioactive wastes and the safe management of radionuclide-contaminated land are global environmental priorities of intense public concern, which require comprehensive knowledge of the long-term behavior of radionuclides in the geosphere. Technetium-99 $\left({ }^{99} \mathrm{Tc}\right)$ is a $\beta$ emitting, high-yield fission product, which is long-lived $(2.1 \times$ $10^{5}$ years) and environmentally persistent in the subsurface at nuclear mega-sites. ${ }^{1-5}$ Technetium is also present in radioactive wastes destined for geological disposal and has a high solubility, bioavailability, and bioaccumulation potential. It is thus a critical risk-driving radionuclide. ${ }^{4-8}$

The solubility of $\mathrm{Tc}$ in the environment is largely governed by its oxidation state. Highly soluble pertechnetate $\left(\mathrm{TcO}_{4}{ }^{-}\right)$ dominates in oxic groundwater, sorbing weakly to geomedia (e.g., ${ }^{9-11}$ ). In contrast, poorly soluble Tc(IV) dominates under anoxic conditions, forming Tc-oxides, -sulfides, or sorbing strongly to mineral phases (e.g., Fe-oxides and sulfide minerals). ${ }^{11-13}$ In many environments, reductive scavenging of $\mathrm{Tc}(\mathrm{VII})$ to poorly soluble $\mathrm{Tc}(\mathrm{IV})$ coincides with the development of microbially mediated $\mathrm{Fe}$ (III)- and sulfatereducing conditions. As a consequence, and in an effort to limit Tc migration in the environment, there has been widespread interest in promoting $\mathrm{Tc}(\mathrm{VII})$ bioreduction in the shallow subsurface. For example, an electron donor such as acetate is added to groundwater to stimulate microbially mediated anaerobic processes. ${ }^{8,11,14-17}$ Electron donor release from radioactive waste packages in a geological disposal facility may also stimulate microbial reduction ${ }^{18}$ and this newly recognized "biobarrier" may serve to limit radionuclide migration through the deep subsurface. ${ }^{19,20}$

To date, work in pure culture, sediment microcosms, flowthrough columns, and in the field, has documented a range of $\mathrm{Tc}(\mathrm{VII})$ reduction mechanisms and $\mathrm{Tc}(\mathrm{IV})$ reduction products. Enzymatic Tc(VII) reduction can be facilitated by a range of microorganisms but is thought to be only modestly important in controlling Tc fate under typical environmental conditions. ${ }^{21,22}$ Instead, $\mathrm{Tc}(\mathrm{VII})$ reduction is dominated by reaction with byproducts of microbial metabolism, principally biogenic $\mathrm{Fe}(\mathrm{II})$ and sulfide. ${ }^{10,23-25}$ This includes abiotic reduction by $\mathrm{Fe}(\mathrm{II})$ in a range of $\mathrm{Fe}(\mathrm{II})$-bearing minerals (e.g., refs

Received: May 11, 2017

Revised: November 10, 2017

Accepted: November 16, 2017

Published: November 16, 2017 
17,20,26-29), as well as sulfide phases. ${ }^{12,16,30}$ Under Fe(III)reducing conditions, and at $\mathrm{Tc}$ concentrations above the predicted solubility threshold of the $\mathrm{TcO}_{2}$ species expected, $\mathrm{Tc}(\mathrm{IV})$ reaction products include $\mathrm{TcO}_{2}$ octahedra/octahedral chains and/or discrete hydrous $\mathrm{TcO}_{2}$-phases that may sorb to $\mathrm{Fe}$-(oxyhydr)oxides. ${ }^{13,20,26,27,31,32} \mathrm{Tc}(\mathrm{IV})$ can also be incorporated into magnetite ${ }^{29}$ and goethite, ${ }^{33}$ and $\mathrm{TcS}_{x}$-like phases have also been observed. ${ }^{12,16,34}$ Further, under these conditions, Tc sorbs strongly to sediments, presumably as $\mathrm{Tc}(\mathrm{IV})$, even below the predicted $\mathrm{TcO}_{2}$ solubility threshold. ${ }^{11,35,36}$

Despite the potential for removal of Tc from groundwater as poorly soluble $\mathrm{Tc}(\mathrm{IV})$, it is clear that with such a long half-life, understanding ${ }^{99} \mathrm{Tc}$ behavior over extended time scales is critically important. For example, reoxidation of $\mathrm{Tc}(\mathrm{IV})$ containing materials may result in Tc remobilization as soluble $\mathrm{Tc}(\mathrm{VII})$, leading to migration. Oxidizing conditions in the shallow subsurface can occur via groundwater perturbations or flooding, while over geological time scales, the introduction of oxic groundwater to a geological disposal facility is also of concern. $^{37-40}$ To date, work exploring the stability of $\mathrm{Tc}(\mathrm{IV})$ reduction products over extended time scales has been relatively sparse, with most studies focusing on short duration (days to several weeks) reoxidation scenarios, typically involving exposure of reduced, $\mathrm{Tc}(\mathrm{IV})$-bearing sediments to $\mathrm{O}_{2}$ or $\mathrm{NO}_{3}{ }^{-}$rich groundwater (e.g., ${ }^{26,32,37,39,41}$ ). In this past work, significant $(20-80 \%)$ Tc remobilization to solution has been reported, but in most cases some $\mathrm{Tc}$ remains as $\mathrm{Tc}(\mathrm{IV})$ within the reoxidized sediment. ${ }^{32,33,37,39,41,42}$ Binding of shortchain $\mathrm{TcO}_{2}$ to $\mathrm{Fe}$-(oxyhydr)oxides has been suggested as a mechanism that limits oxidative dissolution. ${ }^{33}$ Similar studies with Tc-labeled synthetic $\mathrm{Fe}(\mathrm{II})$-bearing mineral systems have also shown $\mathrm{Tc}(\mathrm{IV})$ retention when the minerals are oxidized. $^{12,29,31,33}$ Here, incorporation of $\mathrm{Tc}(\mathrm{IV})$ into mineral lattice sites, physical shielding of $\mathrm{Tc}$ (IV) by $\mathrm{Fe}$ (III) oxidation rinds, and/or oxidative buffering by residual $\mathrm{Fe}$ (II) have all been suggested as mechanisms which could protect $\mathrm{Tc}(\mathrm{IV})$ from oxidative remobilization. ${ }^{26,29,31}$

These studies, conducted over one redox cycle and for relatively short amounts of time (nominally days to several weeks), provide insights into Tc biogeochemical behavior in sediment and mineral systems highlighting that pseudoirreversible binding of a fraction of $\mathrm{Tc}(\mathrm{IV})$ may be possible. However, ${ }^{99} \mathrm{Tc}$ has a long half-life and will likely undergo repeated redox cycling in the natural environment and the impact of such processes has not been investigated. Here, we investigate the hypothesis that multiple redox cycling events can impact on Tc solubility due to molecular scale changes in its speciation and fate. The objectives of this study were to define ${ }^{99} \mathrm{Tc}$ reactivity and fate across repeated redox cycles in nuclear legacy relevant sediments and to define the molecular scale speciation of ${ }^{99} \mathrm{Tc}$ during redox cycling to link these to macro scale remobilization behavior.

Our experiments used acetate as an electron donor to promote microbial reduction pathways in a model sediment system, representative of the Sellafield Ltd. site subsurface that was amended with $\mathrm{Tc}(\mathrm{VII})_{(\mathrm{aq})}$. This led to reduction of $\mathrm{Tc}(\mathrm{VII})$ and creation of $\mathrm{Tc}(\mathrm{IV})_{(\mathrm{S})}$-phases. The reduced sediment was then oxidized (via addition of $\mathrm{O}_{2}$ ) and reduced (via acetate addition) several times. Using sequential extractions, XAS, and TEM, our results detail an increased recalcitrance of sediment-bound $\mathrm{Tc}(\mathrm{IV})$ to oxidative remobilization across multiple redox cycles. This suggests a pathway to enhanced $\mathrm{Tc}(\mathrm{IV})$ retention in sediment systems; a positive prospect for both contaminated land and radioactive waste geological disposal scenarios. However, we also identify the ingrowth of a Tc colloidal phase that is stable under reducing conditions. The presence of ${ }^{99} \mathrm{Tc}$ in a mobile colloidal phase may lead to enhanced mobility of ${ }^{99} \mathrm{Tc}$ in the subsurface and clearly warrants further research. Overall, these data highlight the complex behavior of ${ }^{99} \mathrm{Tc}$ under repeated biogeochemical redox cycling with both $\mathrm{Tc}(\mathrm{IV})$ binding to Fe-phases, and Tc colloid formation impacting its potential fate and mobility. Furthermore, the processes explored in this study have clear implications when considering the eventual fate of other riskdriving, long-lived, redox-active radionuclides (e.g., Se, U, Np, and $\mathrm{Pu}$ ) as they will undoubtedly undergo similar redox cycling processes.

\section{MATERIALS AND METHODS}

Sediment Collection. Sediment was collected from a well characterized $^{43}$ field site (Latitude $54^{\circ} 26^{\prime} 30 \mathrm{~N}$, Longitude $\left.03^{\circ} 28^{\prime} 09 \mathrm{~W}\right)$. The site is representative of the Quaternary unconsolidated alluvial floodplain deposits that underlie the Sellafield Ltd. site. After collection, the sediment was immediately hand-picked to remove larger debris and rock fragments, and then stored in a sealed sterile plastic container at $10{ }^{\circ} \mathrm{C}$ in the dark until use, with experiments starting within 4 weeks of sample collection so as to minimize potential changes to the indigenous microbial community. The sediment characteristics (elemental composition, bulk mineralogy etc.) are summarized in the Supporting Information (SI).

Experimental Approach. We designed our experiments using Tc concentrations of 0.5 and $400 \mu \mathrm{M}$ to allow both straightforward radiometric counting of aqueous ${ }^{99} \mathrm{Tc}$, and at $400 \mu \mathrm{M}$, to permit access to direct spectroscopic and electron microscopy analyses on samples thus allowing us to probe the molecular speciation and fate of the radionuclide. These Tc concentrations approximate to the wasteform environment and/or impacted environments in the immediate vicinity of nuclear facilities rather than typical sub nanomolar concentrations observed in far field impacted environments. ${ }^{7}$

Microcosm Preparation. Using aseptic technique, duplicate large volume microcosms were prepared with sediment $(100 \pm 1 \mathrm{~g})$ and a synthetic groundwater representative of the Sellafield region $(1 \mathrm{~L} \pm 1 \mathrm{~mL}$; see the SI for the Groundwater composition) in $2 \mathrm{~L}$ bottles (Schott, Duran). The headspace was flushed with Ar gas and sealed with an airtight stopper. Prior to microcosm setup, the groundwater had been autoclaved to ensure sterility, flushed with Ar gas, and adjusted to $\mathrm{pH} \sim 7.4$ using weak $\mathrm{NaOH} .^{4}$ Thereafter, $10 \mathrm{mM}$ acetate was added as an electron donor and $0.5 \mu \mathrm{M}\left(30 \mathrm{~Bq} \mathrm{ml}^{-1}\right)$ ammonium pertechnetate (CERCA, France) was spiked into the experiment. Microcosms were incubated in the dark at 21 ${ }^{\circ} \mathrm{C}$ and sampled periodically. Control microcosms were prepared in triplicate and sterilized by autoclaving prior to the addition of $\mathrm{TcO}_{4}{ }^{-}$.

Geochemical Monitoring. Sediment slurry was sampled using aseptic technique under $\mathrm{O}_{2}$ free conditions at each time point and the solids/supernatant were separated by centrifugation at $1.44 \times 10^{4} \mathrm{~g}$ for $10 \mathrm{~min}$. Assuming a density of quartz $\left(2.65 \mathrm{~g} \mathrm{~cm}^{-3}\right)$ for any particles in solution, this centrifugation would sediment particles of $>450 \mathrm{~nm}$ diameter, as predicted by Stokes' Law. For denser particle types, smaller particles would have been sedimented (e.g., $>290 \mathrm{~nm}$ for magnetite $(5.15 \mathrm{~g}$ $\left.\mathrm{cm}^{-3}\right)$ ). To gauge the extent of microbially mediated $\mathrm{Fe}(\mathrm{III})-$ reduction/Fe(II) oxidation, the "bioavailable" $\mathrm{Fe}(\mathrm{II}) / \mathrm{Fe}$ (total) 
Table 1. Details of EXAFS Fitting Parameters ${ }^{a}$

\begin{tabular}{|c|c|c|c|c|c|c|c|c|}
\hline sample & path Tc- & $\mathrm{R}(\AA)$ & $\mathrm{NoP}$ & $\sigma^{2}\left(\AA^{2}\right)$ & $\Delta E^{0}(\mathrm{eV})$ & $\mathrm{S}_{0}{ }^{2}$ & R-factor & $\Delta(\%)$ \\
\hline \multirow[t]{4}{*}{ 1st reduction } & $\mathrm{O}$ & $2.02(1)$ & $6^{*}$ & 0.005 & \multirow[t]{4}{*}{0.80} & \multirow[t]{4}{*}{$0.95^{*}$} & \multirow[t]{4}{*}{0.006} & \multirow[t]{4}{*}{97.5} \\
\hline & $\mathrm{Tc}$ & $2.55(1)$ & $1.36(22)$ & $0.003^{*}$ & & & & \\
\hline & $\mathrm{Fe}$ & $2.62(4)$ & $0.53(30)$ & $0.006^{*}$ & & & & \\
\hline & $\mathrm{O}-\mathrm{Tc}-\mathrm{O}^{m s}$ & $4.05(1)$ & $6^{*}$ & 0.01 & & & & \\
\hline \multirow[t]{4}{*}{ 1st oxidation } & $\mathrm{O}$ & $2.01(1)$ & $6^{*}$ & 0.005 & \multirow[t]{4}{*}{0.31} & \multirow[t]{4}{*}{$0.95^{*}$} & \multirow[t]{4}{*}{0.005} & \multirow[t]{4}{*}{99.8} \\
\hline & $\mathrm{Tc}$ & $2.56(1)$ & $1.36(20)$ & $0.003^{*}$ & & & & \\
\hline & $\mathrm{Fe}$ & $2.61(2)$ & $0.69(28)$ & $0.006^{*}$ & & & & \\
\hline & $\mathrm{O}-\mathrm{Tc}-\mathrm{O}^{m s}$ & $4.03(1)$ & $6^{*}$ & 0.011 & & & & \\
\hline \multirow[t]{4}{*}{2 nd reduction } & $\mathrm{O}$ & $2.01(1)$ & $6^{*}$ & 0.005 & \multirow[t]{4}{*}{0.73} & \multirow[t]{4}{*}{$0.95 *$} & \multirow[t]{4}{*}{0.006} & \multirow[t]{4}{*}{99.6} \\
\hline & $\mathrm{Tc}$ & $2.56(1)$ & $1.17(24)$ & $0.003^{*}$ & & & & \\
\hline & $\mathrm{Fe}$ & $2.63(3)$ & $0.66(30)$ & $0.006^{*}$ & & & & \\
\hline & $\mathrm{O}-\mathrm{Tc}-\mathrm{O}^{m s}$ & $4.04(1)$ & $6^{*}$ & 0.01 & & & & \\
\hline \multirow[t]{4}{*}{ 2nd oxidation } & $\mathrm{O}$ & $2.01(1)$ & $6^{*}$ & 0.005 & \multirow[t]{4}{*}{-0.3} & \multirow[t]{4}{*}{$0.95^{*}$} & \multirow[t]{4}{*}{0.007} & \multirow[t]{4}{*}{100.0} \\
\hline & $\mathrm{Tc}$ & $2.56(1)$ & $0.84(26)$ & $0.003^{*}$ & & & & \\
\hline & $\mathrm{Fe}$ & $2.65(4)$ & $0.69(27)$ & $0.006^{*}$ & & & & \\
\hline & $\mathrm{O}-\mathrm{Tc}-\mathrm{O}^{m s}$ & $4.04(1)$ & $6^{*}$ & 0.011 & & & & \\
\hline \multirow[t]{4}{*}{ 3rd reduction } & $\mathrm{O}$ & $2.01(1)$ & $6^{*}$ & 0.005 & \multirow[t]{4}{*}{0.3} & \multirow[t]{4}{*}{$0.95^{*}$} & \multirow[t]{4}{*}{0.010} & \multirow[t]{4}{*}{99.9} \\
\hline & $\mathrm{Tc}$ & $2.55(1)$ & $0.72(29)$ & $0.003^{*}$ & & & & \\
\hline & $\mathrm{Fe}$ & $2.65(5)$ & $0.71(31)$ & $0.006^{*}$ & & & & \\
\hline & $\mathrm{O}-\mathrm{Tc}-\mathrm{O}^{m s}$ & $4.04(2)$ & $6^{*}$ & 0.011 & & & & \\
\hline
\end{tabular}

${ }^{a} R=$ atomic distance; NoP = number of paths; $\sigma^{2}\left(\AA^{2}\right)=$ Debye-Waller factor; $\Delta E^{0}(\mathrm{eV})=$ energy shift from Fermi level; $\mathrm{S}_{0}{ }^{2}=$ amplitude factor; $\mathrm{R}$ factor $=$ normalized least squares residual. To determine change in Tc-Tc NoP and Tc-Fe NoP their $\sigma^{2}$ were fixed to 0.003 and 0.006 , respectively. The amp $\left(\mathrm{S}_{0}{ }^{2}\right)$ for the $\mathrm{O}$ shell was fixed. *Denotes fixed parameter, ${ }^{m s}$ denotes linear multiple scattering path, and their $\mathrm{R}$ and $\sigma^{2}$ values were calculated as multiples of the single scattering path parameters. $\Delta$ confidence level (\%) that the improvements in the fits with the "Tc-Fe" shell are significantly improved compared to the hydrous $\mathrm{TcO}_{2}$ model alone (see SI) using the F-test. ${ }^{46}$ Errors are presented in parentheses and are $1 \sigma$ of last decimal.

ratio in the sediment was determined by extraction of sediment pellet slurries with $0.5 \mathrm{M} \mathrm{HCl}$ for $1 \mathrm{~h} .{ }^{44} \mathrm{Fe}(\mathrm{II})$ and $\mathrm{Fe}$ (total) was then measured in the supernatant (separated from the solids by centrifugation at $1.44 \times 10^{4} \mathrm{~g}$ for $10 \mathrm{~min}$ ) using the ferrozine assay. ${ }^{45}$ This method may not accurately extract all bioavailable $\mathrm{Fe}$ in sediment systems ${ }^{46}$ but was used in this study to detail gross changes in "bioavailable" solid phase $\mathrm{Fe}$ speciation (i.e., provide an indicator as to the extent of $\mathrm{Fe}$ (III) reduction and $\mathrm{Fe}(\mathrm{II})$ oxidation during redox cycling experiments). At the start of the experiments the total amount of 0.5 $\mathrm{N} \mathrm{HCl}$ extractable "bioavailable" Fe(III) was $5.30 \pm 0.20 \mathrm{mmol}$ $\mathrm{kg}^{-1}$. Total ${ }^{99} \mathrm{Tc}$ concentrations in centrifuged $\left(1.44 \times 10^{4} \mathrm{~g}\right.$ for $10 \mathrm{~min}$ ) solutions taken from sediment slurry samples were measured using liquid scintillation counting with appropriate standards and background subtraction such that the detection limit was $0.17 \mathrm{nM}\left(\sim 10 \mathrm{mBq} \mathrm{ml}^{-1}\right)$ (Wallac Quantulus 1220). The microcosms were also sampled at regular intervals for $\mathrm{pH}$ using calibrated electrodes and a Mettler Toledo digital meter. $\mathrm{UV}$-vis spectroscopy methods were used to measure $\mathrm{NO}_{2}{ }^{-}$, $\mathrm{Mn}$, and $\mathrm{Fe}$ in centrifuged $\left(1.44 \times 10^{4} \mathrm{~g}\right.$ for $\left.10 \mathrm{~min}\right)$ solution samples ${ }^{45,47,48}$ using a Shimadzu UV-1800 UV spectrometer. Throughout, calibrations had typical regressions of $\mathrm{R}^{2}>0.99$. Acetate, $\mathrm{SO}_{4}{ }^{2-}$ and $\mathrm{NO}_{3}{ }^{-}$were measured from the same centrifuged solutions using a Dionex DX120 ion chromatograph. Eh was not routinely measured during experimentation due to sample volume constraints; however, it was measured from centrifuged solution samples taken at the end of the first and third reduction and oxidation periods. The samples used for Eh measurement had been stored at $-80{ }^{\circ} \mathrm{C}$ under Ar prior to analysis. They were then defrosted and centrifuged $(1.44 \times$ $10^{4} \mathrm{~g}$ for $10 \mathrm{~min}$ ) and the solution Eh was measured using a calibrated electrode. Microcosms were also weighed between sampling points to monitor for evaporation, which was found to be negligible.

Redox Cycling Experiments. After initial reduction (signified by the $0.5 \mathrm{M} \mathrm{HCl}$-extractable $\mathrm{Fe}(\mathrm{II}) / \mathrm{Fe}$ (total) ratio reaching $\sim 100 \% \mathrm{Fe}(\mathrm{II})$ ), the microcosms were oxidized with air (containing $\mathrm{O}_{2}$ as the oxidant). Here, the headspace was flushed regularly (every 1-3 days) with $1 \mathrm{~L}$ of gas passed through a $0.22 \mu \mathrm{m}$ filter (80:20 air: $\mathrm{CO}_{2} \mathrm{mix}$ ), to maintain a near neutral $\mathrm{pH}$. This gas treatment continued until the proportion of $0.5 \mathrm{M} \mathrm{HCl}$-extractable $\mathrm{Fe}$ (II) in the sediment had significantly reduced and stabilized between sampling points. At this point, acetate $(5 \mathrm{mM})$ was added as an electron donor to stimulate anaerobic metabolism and the headspace was flushed with $0.22 \mu \mathrm{m}$ filtered Ar. The microcosms were then incubated until the proportion of $0.5 \mathrm{M} \mathrm{HCl}$-extractable $\mathrm{Fe}(\mathrm{II})$ had stabilized between sampling points at between $95-100 \%$ of the total extractable $\mathrm{Fe}$. In total, three full reduction/oxidation events were sampled. Decisions on when to start/stop oxidation treatments were not based on achieving steady state for Tc concentrations in solution.

Acid Extraction of Sediment Samples. Acid extractions were performed on select sediment samples to assess any relationship between $\mathrm{Fe}$ and $\mathrm{Tc}$ in redox-cycled sediments. Here, sediments were sequentially leached with increased molarity $\mathrm{HCl}$ for $30 \mathrm{~min}$ (unless stated), in the order: 0.001, $0.01,0.1,1,2,3,4$, and $6 \mathrm{M}, 6 \mathrm{M}$ for $24 \mathrm{~h}, 6 \mathrm{M}$ for 4 days and, 


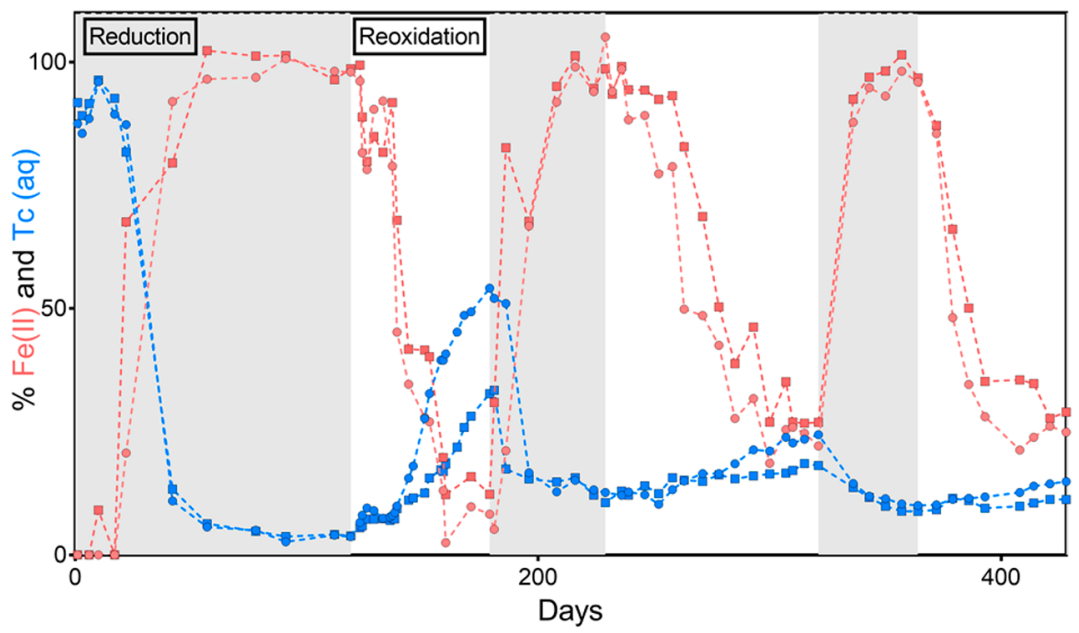

Figure 1. Tc remaining in centrifuged $\left(1.44 \times 10^{4} \mathrm{~g}, 10 \mathrm{~min}\right)$ solutions (blue dashed line) (expressed as a percentage of the original ${ }^{99} \mathrm{Tc}$ spike $(0.5$ $\mu \mathrm{M})$ ) and the $\%$ of $0.5 \mathrm{~N} \mathrm{HCl}$ extractable $\mathrm{Fe}($ total) present as $\mathrm{Fe}(\mathrm{II})$ in sediments (extracted by $0.5 \mathrm{~N} \mathrm{HCl}$ for $1 \mathrm{~h}$; total bioavailable Fe(III) $=5.30$ mmol kg ${ }^{-1}$ ) (red dotted line), for duplicate microcosms (microcosm 1: circles, microcosm 2: squares). Shaded areas denote "reduction events", where microcosms were amended with acetate and kept anaerobic. Unshaded areas denote "oxidation events", where microcosms were oxidized with air $\left(\mathrm{O}_{2}\right)$. The analytical error associated with ${ }^{99} \mathrm{Tc}$ measurements was low $\left(<1 \%\right.$ of the solution ${ }^{99} \mathrm{Tc}$ concentration $)$; the limit of detection for Tc was $0.17 \mathrm{nM}$. The reproducibility of the $0.5 \mathrm{~N} \mathrm{Fe}$ extraction was $\sim \pm 10 \%$ based on repeated measurement $(n=3)$ of the same sample.

finally, in heated aqua regia for $4 \mathrm{~h}$ (modified from a previously published method; $\left.{ }^{49}\right)$. The centrifuged $\left(1.44 \times 10^{4} \mathrm{~g}, 10 \mathrm{~min}\right)$ extracts were analyzed for ${ }^{99} \mathrm{Tc}$ and $\mathrm{Fe}$ using liquid scintillation counting and the ferrozine method, respectively.

Ultrafiltration of Groundwater Samples. Ultrafiltration of solutions was performed at the end of the third reduction and oxidation periods using Nanosep Centrifugal Filters (Pall Corp.; centrifuged at $1.44 \times 10^{4} \mathrm{~g}, 10 \mathrm{~min}$ ) to explore the colloidal/solution distribution of Tc. Two filter sizes were used; $0.2 \mu \mathrm{m}$ and $10 \mathrm{kDa}$, the latter having a geometric mean particle size of $\sim 3 \mathrm{~nm}$ for a globular particle. ${ }^{50}$ The filters were preequilibrated with sample solution prior to use. Technetium concentrations in the filtrate were measured using liquid scintillation counting.

X-ray Absorption Spectroscopy. Higher activity parallel samples (2.5 g sediment in $25 \mathrm{~mL}$ groundwater, at a concentration of $400 \mu \mathrm{M} \mathrm{Tc}(\mathrm{VII})$ ) were incubated at the elevated concentrations required for XAS in order to measure ${ }^{99} \mathrm{Tc}$ speciation in sediment and solution during redox cycling. Sediment was sampled (as previously described) at the end of reduction periods (days $=266,325,380)$ and at the end of two oxidation periods (days $=310$ and 372 ). For oxidation timepoints, sediment samples were rinsed with thoroughly deoxygenated water, under $\mathrm{O}_{2}$ free conditions prior to analysis. ${ }^{32}$ Centrifuged $\left(1.44 \times 10^{4} \mathrm{~g}, 10 \mathrm{~min}\right)$ solution samples for XANES measurement were taken at the end of the second oxidation period and third reduction period. All XAS samples were prepared, packed into airtight, triple contained sample cells, and stored under $\mathrm{O}_{2}$ free conditions. XANES and EXAFS spectra were collected on beamline B18 of Diamond Light Source from the ${ }^{99} \mathrm{Tc}$ K-edge in fluorescence mode at $78 \mathrm{~K}$. Spectra were collected with either a 9 or 36 element Ge detector. XANES data underwent linear combination fitting (LCF) between $\mathrm{Tc}$ (IV) and $\mathrm{Tc}$ (VII) (as ammonium pertechnetate) standards ${ }^{51}$ to provide an indication of the percentage distribution of $\mathrm{Tc}(\mathrm{IV})$ and $\mathrm{Tc}(\mathrm{VII})$ in the samples. EXAFS data were fitted using Athena and Artemis software packages and using relevant information from the literature. ${ }^{52}$ The statistical viability of additional shells was assessed using the F-test. $^{29,53}$ To determine the trend in the Tc-Tc coordination number, the fitting procedure was constrained to fixed values for the passive electron reduction factor $\left(\mathrm{S}_{0}{ }^{2}\right)$ and Debye-Waller factor $\left(\sigma^{2}\right)$ (Table 1$)$.

Transmission Electron Microscopy. Transmission electron microscope (TEM) grids were prepared under $\mathrm{O}_{2}$ free conditions with the groundwater from high activity (XAS) microcosms taken at the end of the third reduction period. Prior to preparation, the groundwater was centrifuged at $1.44 \times$ $10^{4} \mathrm{~g}$ for $10 \mathrm{~min}$ and a small sample of the supernatant was then pipetted on the TEM grid under $\mathrm{O}_{2}$ free conditions. Images were taken using a FEI Tecnai TF20 field emission gun TEM and the particle composition on the TEM grids was analyzed with an Oxford Instruments INCA 350 EDX. Mineral composition was quantified using Selected Area Electron Diffraction (SAED).

16S rRNA Gene Amplicon Pyrosequencing and Data Analysis. DNA from both microcosms was isolated from $\sim 0.2$ $\mathrm{g}$ of sample from the starting sediment (day 0 ), sediments after reduction events (days $=119,229,372)$, and sediment after oxidation events (days $=179,321,428$ ) using the MoBio PowerSoil DNA Isolation Kit (MoBio Laboratories Inc.). PCR for amplicon pyrosequencing was performed using tagged fusion bacterial primers $27 \mathrm{~F}^{54}$ and $338 \mathrm{R},{ }^{55}$ as described previously. $^{56}$

Pyrosequencing was performed using a Roche 454 Life Sciences GS Junior system. The 454 pyrosequencing reads were analyzed using Qiime 1.8 .0 release, ${ }^{57}$ and denoising and chimera removal was performed in Qiime during operational taxonomic units (OTU) picking (at 97\% sequence similarity) with usearch. ${ }^{58}$ Taxonomic classification of all reads was performed in Qiime using the uclust method against the Greengenes database, release $8 / 2013 .{ }^{58}$

Nonmetric multidimensional scaling (NMDS) was performed on Primer v6 (PRIMER-E Ltd., UK), based on a Bray-Curtis similarity matrix ${ }^{59}$ that was calculated using square root transformed relative (\%) abundances of all the identified OTUs of this study. 


\section{RESULTS AND DISCUSSION}

Redox Cycling and Changes in Solution Technetium Concentrations. Sediment microcosms representative of the Sellafield subsurface were run in duplicate to explore the fate of Tc during three reduction/oxidation cycles over $\sim 1.5$ years. The sediment microcosms (1:10, solid: solution ratio; volume 1 L) were amended with an electron donor (10 $\mathrm{mM}$ acetate), spiked with $\mathrm{Tc}$ (VII) $(0.5 \mu \mathrm{M})$ and incubated anaerobically until $\mathrm{Fe}(\mathrm{III})$ - and $\mathrm{SO}_{4}{ }^{2-}$-reducing conditions had developed. Periodically, microcosms were then oxidized with air $\left(\mathrm{O}_{2}\right)$ and then rereduced through further addition of acetate, which promoted microbially mediated reduction following the normal sequence of terminal electron accepting processes (Figure 1 and SI Figure 1). At the end of periods of reduction, the Eh of the microcosms was $\leq-140 \mathrm{mV}$; at the end of periods of oxidation the Eh was $\geq 187 \mathrm{mV}$. These values are similar to past Eh measurements in Sellafield sediment systems. ${ }^{8,39}$ In sterile (oxic) control experiments, redox conditions remained unchanged and Tc remained in the centrifuged solution (1.44 $\times 10^{4} \mathrm{~g}, 10 \mathrm{~min}$; referred to as "solution" throughout the manuscript unless otherwise stated) as expected for $\mathrm{Tc}(\mathrm{VII})$ under oxic/denitrifying conditions (SI Figure $2^{9-11}$ ). In the microbially active experiments, Tc remained in solution until $\sim 20$ days; thereafter, ${ }^{99} \mathrm{Tc}$ was largely scavenged to solids concomitant with $\mathrm{Fe}$ (III)-reduction ( $\sim 94 \%$ of added Tc removed from solution between days 22 and 57, Figure 1). Here, scavenging of Tc was likely dominated by abiotic reduction of $\mathrm{Tc}(\mathrm{VII})$ through reaction with biogenic $\mathrm{Fe}$ (II). ${ }^{10,24}$ After 119 days, the proportion of $0.5 \mathrm{~N} \mathrm{HCl}$ extractable $\mathrm{Fe}$ (total) present as $\mathrm{Fe}$ (II) in solids (herein referred to as extractable $\mathrm{Fe}(\mathrm{II}))$ was $98.3 \pm 0.5 \%$ and the $\mathrm{Tc}$ concentration in solution had stabilized $(96.2 \pm 1.1 \%$ of added Tc removed from solution, $18.2 \pm 0.6 \mathrm{nM}$ remaining in solution) near the theoretical solubility of hydrous $\mathrm{TcO}_{2}(\sim 10$ $\mathrm{nM}$; 35). At this point, oxidation of the microcosms was initiated by flushing the headspace with $0.22 \mu \mathrm{m}$ filtered air $\left(\mathrm{O}_{2}\right.$ being the oxidant) every $1-3$ days for 60 days. This resulted in the reoxidation of extractable Fe(II), and after 60 days of air amendment, the extractable $\mathrm{Fe}$ (II) in solids had stabilized at $10.3 \pm 2.9 \%$ (Figure 1). The oxidation of $\mathrm{Fe}$ (II) was accompanied by significant, yet incomplete Tc remobilization to solution with $43 \pm 15 \%$ of the initial Tc spike remobilised from the sediment after 60 days of oxidation. This level of $\mathrm{Fe}$ (II)-reoxidation and $\mathrm{Tc}$ remobilization during air oxidation is in agreement with past work completed over similar time scales. $32,33,37,39,41$

After oxidation had stabilized with a measured sediment extractable $\mathrm{Fe}(\mathrm{II})$ proportion of $10.3 \pm 2.9 \%$ (day 179, Figure 1 ), bioreduction was again stimulated with the addition of 5 $\mathrm{mM}$ acetate and with purging of the headspace with $0.22 \mu \mathrm{m}$ filtered Ar. Here, microbially mediated Fe(III)-reducing conditions rapidly re-established alongside removal of $\mathrm{Tc}$ from solution. During this second period of bioreduction, extractable $\mathrm{Fe}(\mathrm{II})$ in solids reached $\sim 100 \%$ within 35 days (Figure 1), and removal of $\mathrm{SO}_{4}{ }^{2-}$ from solution also occurred, suggesting the onset of microbially mediated $\mathrm{SO}_{4}{ }^{2-}$ reduction (see SI Figure 1). Interestingly, despite these strongly reducing conditions, a greater proportion of Tc remained in solution when compared to the first reduction period $(11.6 \pm 1.4 \%$ compared to $3.8 \pm 0.1 \%$; Figure 1). After 229 days, the experiments were again reoxidized through repeated (every 13 days) purging of the headspace with air for a period of 92 days. During the second period of reoxidation, a larger proportion of extractable $\mathrm{Fe}(\mathrm{II})$ remained stable in the solids $(24.5 \pm 3.4 \%$ by day 321$)$, suggesting that there was formation of an $\mathrm{Fe}$ (II)-bearing phase that was more resistant to oxidation such as magnetite. In addition, less $\mathrm{Tc}$ was remobilized into solution during the second reoxidation $(43 \pm 15 \%$ in the first oxidation period vs $21 \pm 4 \%$ in the second; Figure 1). Finally, a third period of bioreduction (addition of $5 \mathrm{mM}$ acetate, headspace purging with filtered $\mathrm{Ar}$, and anaerobic incubation for 43 days) and oxidation (controlled exposure to filtered air for 64 days) was completed. At the end of the third period of reduction, $96.4 \pm 0.6 \%$ of the extractable $\mathrm{Fe}$ was present as $\mathrm{Fe}(\mathrm{II})$ and $9.4 \pm 0.9 \%$ of the added Tc remained in solution. After subsequent reoxidation, the extractable sediment $\mathrm{Fe}$ (II) content again stabilized at around $26.4 \pm 1.1 \%$ and $\mathrm{Tc}$ in solution increased to $13.1 \pm 2.6 \%$. Overall, during redox cycling, a significant fraction $(25 \%)$ of extractable $\mathrm{Fe}(\mathrm{II})$ became resistant to oxidation, potentially due to ingrowth of recalcitrant $\mathrm{Fe}$ (II) bearing phase(s). By contrast, the total pool of $0.5 \mathrm{~N} \mathrm{HCl}$ extractable Fe remained relatively constant during redox cycling (see the SI and SI Table 1). For Tc, there was a significant increase in Tc measured in solution between the first $(3.8 \pm 0.1 \%)$ and third reduction periods $(9.4 \pm 0.8 \%)$. In contrast, during oxidation, the sediment associated Tc became progressively more resistant to remobilization (43 $\pm 15 \%$ remobilised to solution during the first oxidation compared to $13.1 \pm 2.6 \%$ in the third). This suggests that with repeated redox cycling, a significant fraction of sediment associated Tc becomes more strongly resistant to remobilization while at the same time, surprisingly, the concentration of Tc that remains in solution under reducing conditions increases.

Technetium Extractability and Speciation on Sediments during Redox Cycling. In order to further investigate the relationship between $\mathrm{Tc}$ and $\mathrm{Fe}$ in the sediment we used acid extractions on solid phases at the end-points of the first and third reoxidation periods (days 179 and 428, Figure 1). The samples showed the same general Tc and Fe dissolution trends in the acid extractions (Figure 2; concentration data presented in SI Table 2), but the Tc and Fe from the first reoxidation period samples were always more susceptible to acid leaching than those in samples from the third reoxidation period. This suggests that there is an increased recalcitrance to remobilization for Tc with repeated redox cycling. Further, in both treatments, after sequential leaching for 30 min with $\mathrm{HCl}$ concentrations ranging from 0.001 to $6 \mathrm{M}$, the slope of Tc vs Fe dissolution was always $>1$. This indicated that most of the Tc was heterogeneously distributed on the mineral surfaces, as also indicated by an enhanced release of available Tc ( 40$80 \%)$ compared to $\mathrm{Fe}(<20 \%)$ in the first and third reoxidation samples, respectively. However, the Tc became more resistant to acid leaching with repeated redox cycling (Figure 2), with 25 $\pm 5 \%$ (first reoxidation) and $52 \pm 8 \%$ (third reoxidation) resistant to leaching with $6 \mathrm{M} \mathrm{HCl}$ for $30 \mathrm{~min}$. Indeed, an aggressive, oxidizing aqua regia leach was required for full dissolution of the Tc from the solids (Figure 2; SI Table 2).

The marked decrease in Tc susceptibility toward remobilization (Figure 1) and the increased recalcitrance of Tc to acid leaching (Figure 2) between the first and third periods of reoxidation confirm that the Tc became more strongly bonded within the sediment as a result of repeated redox cycling. This increased recalcitrance to oxidative remobilization may be associated with enhanced $\mathrm{Tc}$ association with $\mathrm{Fe}$ in the sediments. Indeed, Fe(II) has been suggested to act as a buffer 


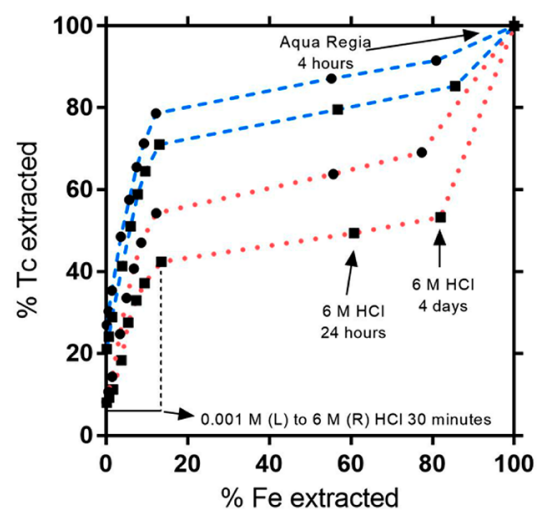

Figure 2. Cumulative dissolution of Tc versus $\mathrm{Fe}$ from select sediment samples. Samples are the 1st oxidation (day 179, blue dashed lines, microcosm 1: circles, microcosm 2: squares) and 3rd oxidation (day 428, red dotted lines, microcosm 1: circles, microcosm 2: squares). The $\left[\mathrm{H}^{+}\right]$in the $30 \mathrm{~min}$ extraction was increased from 0.001 to 0.01 $\mathrm{M}, 0.1 \mathrm{M}, 1 \mathrm{M}, 2 \mathrm{M}, 3 \mathrm{M}, 4 \mathrm{M}$, and, $6 \mathrm{M} \mathrm{HCl}$, with the final three extractions being $6 \mathrm{M} \mathrm{HCl}$ for $24 \mathrm{~h}, 6 \mathrm{M} \mathrm{HCl}$ for 4 days, and heated aqua regia for $4 \mathrm{~h}$. The axes are specific to the concentration of Tc or Fe extracted per sample, with $100 \%$ being the maximum amount of Tc or Fe extracted from that sample (concentration data are presented in SI Table 2). The final aqua regia digest extracted close to all of the available sediment associated Tc per sample, and $\sim 25 \%$ of the total sediment Fe as measured by XRF (3.71 wt \%).

for $\mathrm{Tc}(\mathrm{IV})$ oxidative remobilization in sediment and clay systems $^{28,32}$ and $\mathrm{Tc}(\mathrm{IV})$ may have become physically protected from remobilization through bonding to and/or armoring by $\mathrm{Fe}(\mathrm{II}) / \mathrm{Fe}$ (III) oxidation products, or via incorporation into $\mathrm{Fe}$ minerals. ${ }^{26,29,31,32}$ We also note that past work ${ }^{60}$ has identified possible oxidation of $\mathrm{Tc}(\mathrm{IV})$ by $\mathrm{Fe}(\mathrm{III})$ at acidic $\mathrm{pH}$, but in this study $\mathrm{Fe}(\mathrm{III})$ mediated $\mathrm{Tc}(\mathrm{IV})$ oxidation appears to be of minimal importance. This is demonstrated by the fact that the samples that underwent three redox cycles had a higher proportion of $\mathrm{Fe}(\mathrm{III})$ (Figure 1; SI Table 2) yet showed stronger Tc retention (Figure 2) when compared to the samples that underwent one redox cycle (Figure 1; SI Table 2).

To further assess potential changes in the Tc speciation and coordination environment in these sediment systems, we undertook X-ray Absorption Spectroscopy (XAS) on a select group of parallel experiments run at the higher $(\sim 0.4 \mathrm{mM}) \mathrm{Tc}$ concentrations necessary for detection by XAS. Data were collected at the end of the first, second, and third reduction periods, and at the end of the first and second oxidation periods (see SI). All the Tc K-edge X-ray Absorption Near Edge (XANES) spectra aligned with a Tc(IV) reference sample, confirming that there was no significant $\mathrm{Tc}(\mathrm{VII})$ in any of the samples, regardless of whether they were taken from reduced or reoxidized sediments (Figure $3 \mathrm{~A}$ ). Further, none of the $\mathrm{Tc}$ XANES spectra had evidence of a double peak near the white line which can be indicative of $\mathrm{Tc}$ incorporation in $\mathrm{Fe}$ (oxyhydr)oxides. ${ }^{29,61}$

Analysis of the Extended X-ray Absorption Fine Structure (EXAFS) Fourier transform (FT) data for all samples showed two shells of backscatters were present; the first shell at $\sim 2.0 \AA$ and the second shell at $\sim 2.5 \AA$ (Figure $3 \mathrm{~B}$ and C). There was also a consistent trend in decreasing FT amplitude for the $\sim 2.5$ $\AA$ backscattering shell across the redox cycles (Figure 3B), suggesting a reduced occupancy for backscatterers in this shell with repeated redox cycling. Broadly, these data are similar to the model for $\mathrm{Tc}(\mathrm{IV}) \mathrm{O}_{2} \cdot \mathrm{xH}_{2} \mathrm{O}$ chains ${ }^{13}$ and as seen in several studies where $\mathrm{Tc}$ is present in environmental systems (e.g., ${ }^{20,26,32,62}$ ). The $\mathrm{Tc}(\mathrm{IV}) \mathrm{O}_{2} \cdot \mathrm{xH}_{2} \mathrm{O}$ coordination environment was therefore used as the starting point for modeling. The data were initially fitted with fixed $\mathrm{S}_{0}{ }^{2}$ and $\sigma^{2}$ values and with 6 O backscatterers at $2.0 \AA$, with the best fits realized by optimizing the number of Tc backscatterers at $\sim 2.5 \AA$ (see SI Table 3). This modeling approach suggested that the average coordination number of Tc in the backscattering shell at $\sim 2.5 \AA$ decreased during the redox cycles, starting at $1.2 \pm 0.1 \mathrm{Tc}$ for the first reduction and falling to $0.7 \pm 0.1 \mathrm{Tc}$ by the third reduction (see SI Table 3). Interestingly, the observed decrease in the Tc coordination number at $\sim 2.5 \AA$ implies that a shortening of the octahedral chain length in $\mathrm{Tc}(\mathrm{IV}) \mathrm{O}_{2} \cdot \mathrm{xH}_{2} \mathrm{O}$ chains ${ }^{13}$ is occurring during the redox cycles. In the "hydrous $\mathrm{TcO}_{2}$ " model, a $\mathrm{Tc}$ coordination number of two represents an infinite chain as each central Tc atom is neighbored by two Tc atoms, a coordination number of one represents a $\mathrm{TcO}_{2}$ dimer, and a coordination number of zero represents a $\mathrm{TcO}_{2}$ monomer. These fitting results (SI Figure 3 and Table 3 ) suggest that dimers dominate during the first cycle of reduction and oxidation, tending toward monomers with repeated redox
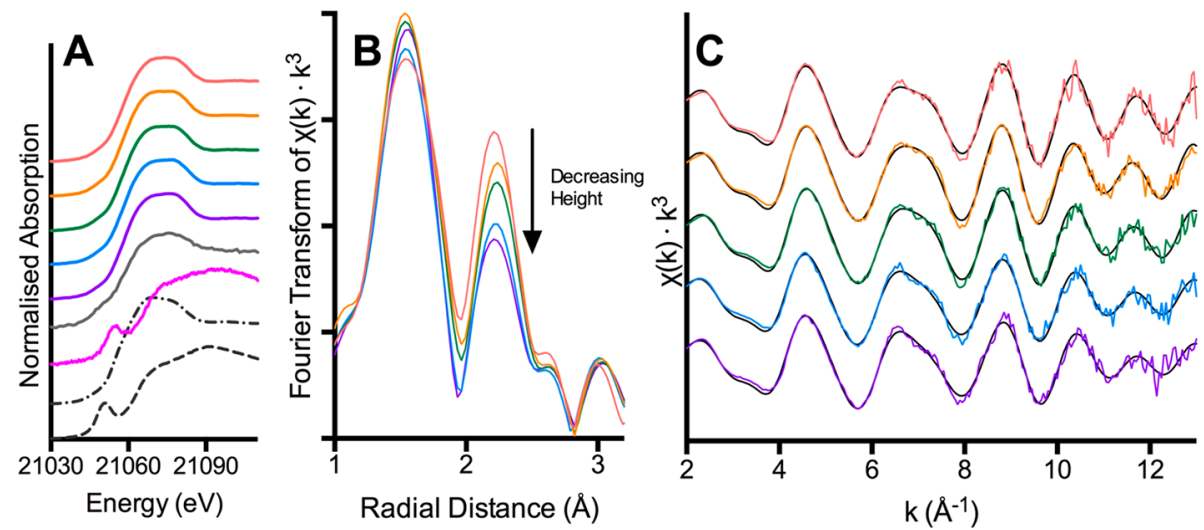

- First Reduction

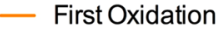

- Second Reductior

- Second Oxidation

- Third Reduction

- Reduced (Aq)

- Oxidised (Aq)

-- $\mathrm{TcO}_{2} \cdot \mathrm{xH}_{2} \mathrm{O}$ referer

--. $\mathrm{TcO}_{4}^{-}$reference

Figure 3. XAS data for ${ }^{99} \mathrm{Tc}$ in reduced and oxidized sediment samples, and solutions separated from the sediment by centrifugation. Panels: A; Tc K-edge XANES spectra for reduced and oxidized sediment, solution samples from reduction and oxidation samples, and reference spectra (from Hess et al., 2004; 51). B; Nonphase shifted Fourier transform of $k^{3}$-weighted EXAFS spectra calculated over a k range of $3.5-13 \AA^{-1}$, with their best fit models (including "short Fe" interaction), and $\mathrm{C}$; $k^{3}$-weighted EXAFS spectra (colored lines) with their best-fit models. For comparison, representative EXAFS spectra for $\mathrm{TcO}_{2}$ and $\mathrm{Tc}(\mathrm{IV})$ associated with magnetite can be found in refs 59 and 29. 
cycling. However, the EXAFS between $10.5-13 \mathrm{~K}$ in the samples also had features that were not fully resolved with this model alone. Reflecting this, Tc binding within sediments via an edge-sharing "short $\mathrm{Fe}$ " octahedron at $\sim 2.6 \AA$ was also considered in fitting (Figure $3 \mathrm{~B}$ and $\mathrm{C}$; Table 1). This has been attributed to attachment of the $\mathrm{TcO}_{2}$ chains at $\mathrm{Fe}-\mathrm{O}$ surfaces. $^{26,31,32,63}$ In all cases, this additional contribution from a "short Fe" backscatterer at $\sim 2.6 \AA$ improved the best fits (Table 1). As expected, these constrained fits also showed a trend of decreasing Tc coordination number at $\sim 2.5 \AA$ with progressive redox cycles, from $1.4 \pm 0.2$ in the first reduction to $0.7 \pm 0.3$ in the third reduction, and consistent with shortening of the $\mathrm{TcO}_{2}$ chain. At the same time, there was an increase in both the proportion of $\mathrm{Tc}-\mathrm{Fe}$ bonding at $\sim 2.6 \AA$, and the confidence that the additional "short Fe" improved the fits with repeated redox cycling (Table 1, SI Table 3)..$^{20,29,64}$ This confirms the samples can be consistently fitted with a physical model showing a relative decrease in the $\mathrm{TcO}_{2}$ chain length, coupled with a proportional increase in $\mathrm{Tc}-\mathrm{Fe}$ bonding via attachment to surface $\mathrm{Fe}-\mathrm{O}$ sites throughout progressive redox cycles. Importantly, the molecular scale changes in $\mathrm{Tc}(\mathrm{IV})$ binding observed in these systems offer key insights into bulk $\mathrm{Tc}$ behavior in the sediments. Specifically, with repeated redox cycling, we see evidence for hydrous $\mathrm{TcO}_{2}$ chain shortening and for the $\mathrm{TcO}_{2}$ chains to become increasingly associated with edge-sharing $\mathrm{Fe}-\mathrm{O}$. These molecular scale observations then manifest as a decrease in oxidative remobilization of $\mathrm{Tc}$ with repeated redox cycles, and are supported by the observation that bonding of short chain hydrous $\mathrm{TcO}_{2}$ protects or renders $\mathrm{Tc}$ (IV) less susceptible to oxidation. ${ }^{32}$ In summary, our data suggest that repeated redox cycling produces a shorter $\mathrm{TcO}_{2}$ chain that is strongly bonded to $\mathrm{Fe}-\mathrm{O}$ in sediments. In turn, and in agreement with the sequential extraction data, these molecular scale observations are linked to the increased recalcitrance of sediment-associated $\mathrm{Tc}(\mathrm{IV})$ to remobilization as seen with repeated redox cycling.

Technetium Colloid Formation. While the sediment associated Tc appeared to become more recalcitrant to oxidative remobilization, the concentration of $\mathrm{Tc}$ remaining in the aqueous phase increased during successive redox cycles (Figure $1 ; \sim 4 \%$ after the first reduction cycle to $\sim 13 \%$ at the end of the third oxidation cycle). Past work has highlighted the presence of a "soluble" Tc phase under reducing conditions with both colloidal $\mathrm{Tc}(\mathrm{IV})^{16,65,66}$ or $\mathrm{Tc}(\mathrm{IV})$ carbonate complexes $^{67}$ reported or inferred. To examine this further, centrifugation and filtration of the separated aqueous phase was used to assess the presence of Tc colloids in these systems. In the lower concentration microcosms $(0.5 \mu \mathrm{M}$ starting concentration of $\mathrm{Tc}$ ) after the third oxidation event, practically all of the $\mathrm{Tc}$ in the aqueous phase $(98.2 \pm 5.5 \%)$ passed through a $10 \mathrm{kDa}(\sim 3 \mathrm{~nm})$ filter. In contrast, after the third reduction event, $94.5 \pm 3.0 \%$ of the Tc passed through a 200 $\mathrm{nm}$ filter but only $65.9 \pm 0.1 \%$ through a $10 \mathrm{kDa}(\sim 3 \mathrm{~nm})$ filter, suggesting that approximately one-third of the Tc was present as a colloidal fraction of between $\sim 3-200 \mathrm{~nm}$ at the end of the third reduction cycle. This is consistent with past work that has documented elevated $\mathrm{Tc}(\mathrm{IV})$ concentrations in the aqueous phase above the theoretical solubility threshold for hydrous $\mathrm{TcO}_{2}{ }^{8,16,66,68}$ The remaining $\sim 2 / 3$ of the $\mathrm{Tc}$ was presumably present as $\mathrm{Tc}(\mathrm{IV})$ aquo-ions or complexed $\mathrm{Tc}(\mathrm{IV})$, or colloidal nanoparticles with a size of $<3 \mathrm{~nm}$. In the higher Tc concentration samples run for XAS, we were able to analyze the solution from the third reducing cycle using both XAS and
TEM approaches. The TEM analyses showed clear evidence for colloids with Fe-rich aggregates of 20-100 nm diameter clearly visible. These colloids had clear Tc and Fe signals in EDX spectra (Figure 4). Indeed, the aggregates seemed to be

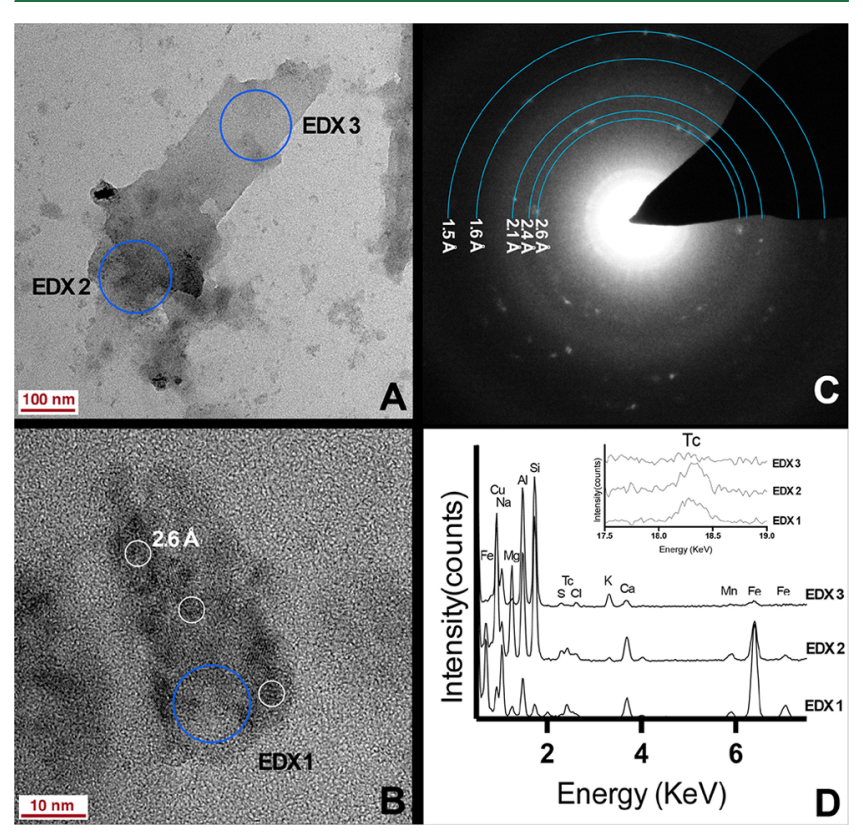

Figure 4. Panels A and B are TEM images of colloids at the end of the third reduction period; selected areas with lattice spacings of $2.6 \AA$ are signified by white circles; blue circles correspond to the areas where energy dispersive X-ray (EDX) spectra were collected. Panel C shows selected area electron diffraction of the particle in panel $B$, light blue lines show measured $d$-spacings $(\AA)$ of the diffraction spectrum. Panel D shows EDX data collected from Panels A and B.

composed of 5-10 $\mathrm{nm}$ nanoparticles and SAED (Figure 4) on the TEM samples, were consistent with magnetite formation, a mineral formed both during microbially mediated $\mathrm{Fe}(\mathrm{III})$ reduction $^{69}$ and when $\mathrm{Tc}(\mathrm{VII})$ reacts with aqueous $\mathrm{Fe}(\mathrm{II}){ }^{31}$ We were also able to obtain Tc K-edge XANES data for the third reduction and second reoxidation solution cycle samples despite their low concentration (Figure 3A). Here, the XANES spectrum for the reduced sample was clearly $\mathrm{Tc}(\mathrm{IV})$-like in structure and linear combination fitting between $\mathrm{Tc}(\mathrm{IV})$ and $\mathrm{Tc}(\mathrm{VII})$ standards confirmed that $\mathrm{Tc}(\mathrm{IV})$ dominated the sample (see SI Table 4). For comparison, XANES data from the solution sample taken during oxidizing conditions clearly resembled $\mathrm{Tc}(\mathrm{VII})$ (Figure $3 \mathrm{~A}^{51}{ }^{5}$ ).

Confirmation by ultrafiltration and TEM of iron (oxyhydr)oxide colloid associated $\mathrm{Tc}$, which appears to be present as $\mathrm{Tc}$ (IV) under reducing conditions in these experiments, has significant implications for the mobility of Tc as colloids can greatly increase radionuclide migration in the subsurface. ${ }^{70,71}$ Indeed, the significantly enhanced concentration of colloid bound $\mathrm{Tc}(\mathrm{IV})$ in these experiments under reducing conditions, when compared to the expected solubility for $\mathrm{TcO}_{2}$ (as high as $\sim 33 \mu \mathrm{M}$ in our higher activity experiments compared to a predicted solubility of $\sim 10 \mathrm{nM}),{ }^{35}$ highlights the need for further work on these phases, for example, understanding $\mathrm{Tc}$ (IV)-Fe (oxyhydr)oxide colloid formation pathways, and stability in environmental systems. ${ }^{29,31}$ Also, this study did not determine changes in dissolved organics (beyond acetate, SI Figure 1) during redox cycling. As dissolved organics have been 
implicated in Tc behavior in environmental systems (including Tc(IV)-colloids) (e.g., ${ }^{72,73}$ ), their role in longer-term redox cycling studies warrants further investigation.

Microbial Community Response to Redox Cycling. $16 \mathrm{~S}$ rRNA gene amplicon pyrosequencing was also used to assess the microbial community response to repeated redox cycles, in both microcosms. Analysis was possible in the low Tc concentration experiments for the starting sediment and at the end points of each reduction and oxidation event (Figure 1; days $=0,119,179,229,321,372,428)$. Overall, the results show a diverse microbial community in all sequenced samples (see SI Figure 4 and Table 6), and sequences related to known $\mathrm{Fe}(\mathrm{III})$ - and $\mathrm{Tc}(\mathrm{VII})$-reducing genera, most notably the deltaproteobacteria Geobacter ${ }^{24}$ and Anaeromyxobacter ${ }^{74}$ were detected. Additionally, there were broader responses in the microbial community compositions to oxidizing or reducing conditions. For example, organisms affiliated with obligate anaerobic Firmicutes of the class Clostridia increased in relative abundance after reduction events, and were less abundant in the community profiles after every oxidation event (SI Figure 4 and Table 6). The opposite correlation was noted within the betaproteobacteria, where close affiliates of the family Comamonadaceae, the genus Azospira, and the order Burkholderiales (which all exhibit aerobic/microaerophilic metabolisms) generally increased in abundance during oxidizing cycles. Similarities between samples based on microbial community composition were explored further using nonmetric multidimensional scaling (NMDS) $)^{59}$ and this showed that oxidation periods had more of an impact on sediment microbial community structure when compared to reduction periods (SI Figure 5).

Implications for Technetium Behavior in the Environment. Here, for the first time we have shown that during repeated redox cycles, $\mathrm{Tc}(\mathrm{IV})$ becomes increasingly strongly bound to sediments. Spectroscopic analysis confirmed a correlation between $\mathrm{Tc}(\mathrm{IV})$ recalcitrance to reoxidation and molecular scale changes in Tc(IV) speciation. Repeated redox cycling prompted a shortening of $\mathrm{TcO}_{2}$ chains and an increase in associations with $\mathrm{Fe}-\mathrm{O}$ edge sites in the sediments. At the same time, chemical extractions confirmed an increase in Tc strongly associated with the sediments with successive redox cycles and that $\mathrm{Fe}$ (II) may also play a role in buffering sediment associated $\mathrm{Tc}(\mathrm{IV})$ oxidative remobilization. This suggests that the current literature which only addresses single oxidation events, may overestimate the influence of oxidation on longterm Tc mobility. By contrast, analysis of solutions showed an $\sim 3000 \times$ enhancement in Tc concentrations after several redox cycles compared to those predicted from thermodynamic calculations, with analysis (ultrafiltration and TEM) documenting the presence of an Fe bearing colloidal phase in solution that also contains Tc under anoxic conditions. This has significant and, as yet, largely unexplored implications for $\mathrm{Tc}$ mobility in reducing environments.

Overall, this study has revealed a number of unique observations on the environmental behavior of technetium in long duration redox cycling experiments and emphasizes the value of this longer-term approach in refining models of the environmental behavior of this radionuclide. Indeed, radionuclide fate upon multiple redox cycling seems to be a largely unexplored yet critical variable in predicting the longer-term environmental behavior of Tc, and by implication may be significant for other long-lived radioactive contaminants such as $\mathrm{Se}, \mathrm{Np}, \mathrm{U}$, and $\mathrm{Pu}$. Going forward, it is important to understand whether these radionuclides respond to ephemeral redox conditions; further, experimentation needs to move from static microcosms systems to more dynamic systems (e.g., columns/ lysimeters) (e.g., ref 75).

\section{ASSOCIATED CONTENT}

\section{Supporting Information}

The Supporting Information is available free of charge on the ACS Publications website at DOI: 10.1021/acs.est.7b02426.

Supplementary sections presenting ancillary data, extra information on methods, and Tables and Figures for control experiments, additional geochemical indicators, sediment characterization data, sequential extraction concentration data, alternative EXAFS fits, XANES linear combination fitting, and microbial community data (PDF)

\section{AUTHOR INFORMATION}

\section{Corresponding Author}

*Phone: +44 (0) 161306 0514; e-mail: gareth.law@ manchester.ac.uk.

\section{ORCID}

Katherine Morris: 0000-0002-0716-7589

Samuel Shaw: 0000-0002-6353-5454

J. Frederick W. Mosselmans: 0000-0001-6473-2743

Gareth T. W. Law: 0000-0002-2320-6330

Present Addresses

"Civil and Environmental Engineering, University of Strathclyde, Glasgow, G1 1XQ, UK.

${ }^{\perp}$ School of Forensic and Applied Sciences, University of Central Lancashire, Preston, PR1 2HE, UK.

\section{Notes}

The authors declare no competing financial interest.

\section{ACKNOWLEDGMENTS}

N.K.M.W. acknowledges the UK EPSRC for PhD funding. This work was supported by the NERC LO-RISE (NE/L000547/1) consortium, which is part of the NERC RATE program (Radioactivity and the Environment) and the NERC BIGRAD consortium (NE/H007768/1). The RATE programme is cofunded by the Environment Agency and Radioactive Waste Management Ltd. Diamond Light Source is acknowledged for beamtime (SP7593, 10163, and 12767). We also thank Katie Law, Alistair Bewsher, Thomas Neill, and Steve Parry.

\section{REFERENCES}

(1) Morris, K.; Butterworth, J. C.; Livens, F. R. Evidence for the remobilization of Sellafield waste radionuclides in an intertidal salt marsh, West Cumbria, U.K. Estuarine, Coastal Shelf Sci. 2000, 51, 613625 .

(2) Lloyd, J. R.; Renshaw, J. C. Bioremediation of Radioactive Waste: Radionuclide-Microbe Interactions in Laboratory and Field-Scale Studies. Curr. Opin. Biotechnol. 2005, 16, 254-260.

(3) Newsome, L.; Morris, K.; Lloyd, J. R. The biogeochemistry and bioremediation of uranium and other priority radionuclides. Chem. Geol. 2014, 363, 164-184.

(4) McKenzie, H. M.; Coughlin, D.; Laws, F.; Stamper, A. Groundwater Annual Report 2011; Sellafield Ltd, 2011.

(5) Lee, M.; Um, W.; Wang, G.; Kruger, A. A.; Lukens, W. W.; Rousseau, R.; Glezahou, V. A. Impeding ${ }^{99}$ Tc (IV) mobility in novel waste forms. Nat. Commun. 2016, 7, 1-6. 
(6) Smith, V.; Fegan, M.; Pollard, D.; Long, S.; Hayden, E.; Ryan, T. P. Technetium-99 in the Irish marine environment. J. Environ. Radioact. 2001, 56, 269-284.

(7) Icenhower, J.; Qafoku, N.; Martin, W.; Zachara, J. M. The Geochemistry of Technetium: A Summary of the Behavior of an Artificial Element in the Natural Environment; U.S. Department of Energy, 2008.

(8) Law, G. T. W.; Geissler, A.; Boothman, C.; Burke, I.; Livens, F. R.; Lloyd, J. R.; Morris, K. Role of nitrate in conditioning aquifer sediments for technetium bioreduction. Environ. Sci. Technol. 2010, 44, 150-155.

(9) Liu, D. J.; Fan, X. H. Adsorption behavior of ${ }^{99} \mathrm{Tc}$ on $\mathrm{Fe}, \mathrm{Fe}_{2} \mathrm{O}_{3}$ and $\mathrm{Fe}_{2} \mathrm{O}_{4}$. J. Radioanal. Nucl. Chem. 2005, 264, 691-698.

(10) Burke, I. T.; Boothman, C.; Lloyd, J. R.; Mortimer, R. J. G.; Livens, F. R.; Morris, K. Effects of Progressive Anoxia on the Solubility of Technetium in Sediments. Environ. Sci. Technol. 2005, 39, 41094116.

(11) Lear, G.; McBeth, J. M.; Boothman, C.; Gunning, D. J.; Ellis, B. L. B. L.; Lawson, R. S.; Morris, K.; Burke, I. T.; Bryan, N. D.; Brown, A. P.; Livens, F. R.; Lloyd, J. R. Probing the Biogeochemical Behavior of Technetium Using a Novel Nuclear Imaging Approach. Environ. Sci. Technol. 2010, 44, 156-162.

(12) Wharton, M. J.; Atkins, B.; Charnock, J. M.; Livens, F. R.; Pattrick, R. A. D.; Collison, D. An X-Ray Absorption Spectroscopy Study of the Coprecipitation of Tc and Re with Mackinawite (FeS). Appl. Geochem. 2000, 15, 347-354.

(13) Lukens, W. W.; Bucher, J. I. J.; Edelstein, N. M.; Shuh, D. K. Products of pertechnetate radiolysis in highly alkaline solution: Structure of $\mathrm{TcO}_{2} \cdot \mathrm{xH}_{2} \mathrm{O}$. Environ. Sci. Technol. 2002, 36, 1124-1129.

(14) Istok, J. D.; Senko, J. M.; Krumholz, L. R.; Watson, D.; Bogle, M. A.; Peacock, A.; Chang, Y.-J.; White, D. C. In situ bioreduction of technetium and uranium in a nitrate-contaminated aquifer. Environ. Sci. Technol. 2004, 38, 468-475.

(15) Wilkins, M. J.; Livens, F. R.; Vaughan, D. J.; Beadle, I.; Lloyd, J. $\mathrm{R}$. The influence of microbial redox cycling on radionuclide mobility in the subsurface at a low-level radioactive waste storage site. Geobiology 2007, 5, 293-301.

(16) Lee, J. H.; Zachara, J. M.; Fredrickson, J. K.; Heald, S. M.; McKinley, J. P.; Plymale, A. E.; Resch, C. T.; Moorea, D. A. Fe(II)and sulfide-facilitated reduction of ${ }^{99} \mathrm{Tc}(\mathrm{VII}) \mathrm{O}_{4}{ }^{-}$in microbially reduced hyporheic zone sediments. Geochim. Cosmochim. Acta 2014, 136, 247-264.

(17) Thorpe, C. L.; Boothman, C.; Lloyd, J. R.; Law, G. T. W.; Bryan, N. D.; Atherton, N.; Livens, F. R.; Morris, K. The Interactions of Strontium and Technetium with Fe(II) Bearing Biominerals: Implications for Bioremediation of Radioactively Contaminated Land. Appl. Geochem. 2014, 40, 135-143.

(18) Rizoulis, A.; Steele, H. M.; Morris, K.; Lloyd, J. R. The potential impact of anaerobic microbial metabolism during the geological disposal of intermediate-level waste. Mineral. Mag. 2012, 76, 32613270.

(19) Behrends, T.; Krawczyk-Barsch, E.; Arnold, T. Implementation of microbial processes in the performance assessment of spent nuclear fuel repositories. Appl. Geochem. 2012, 27, 453-462.

(20) Brookshaw, D. R.; Pattrick, R. A. D.; Bots, P.; Law, G. T. W.; Lloyd, J. R.; Mosselmans, J. F. W.; Vaughan, D. J.; Dardenne, K.; Morris, K. Redox interactions of $\mathrm{Tc}(\mathrm{VII}), \mathrm{U}(\mathrm{VI})$ and $\mathrm{Np}(\mathrm{V})$ with microbially reduced biotite and chlorite. Environ. Sci. Technol. 2015, 79, 13139-13148.

(21) Lloyd, J. R.; Macaskie, L. E. A novel PhosphorImager-based technique for monitoring the microbial reduction of technetium. Appl. Environ. Microbiol. 1996, 62, 578-582.

(22) Lloyd, J. R.; Ridley, J.; Khizniak, T.; Lyalikova, N. N.; Macaskie, L. E. Reduction of technetium by Desulfovibrio desulfuricans: biocatalyst characterization and use in a flowthrough bioreactor. Appl. Environ. Microbiol. 1999, 65, 2691-2696.

(23) Lloyd, J. R.; Nolting, H.-F.; Sole, V. A.; Bosecker, K.; Macaskie, L. E. Technetium reduction and precipitation by sulfate-reducing bacteria. Geomicrobiol. J. 1998, 15, 45-58.
(24) Lloyd, J. R.; Sole, V. A.; Van Praagh, C. V.; Lovley, D. R. Direct and $\mathrm{Fe}(\mathrm{II})$-mediated reduction of technetium by $\mathrm{Fe}(\mathrm{III})$-reducing bacteria. Appl. Environ. Microbiol. 2000, 66, 3743-3749.

(25) Fredrickson, J. K.; Zachara, J. M.; Kennedy, D. W.; Kukkadapu, R. K.; McKinley, J. P.; Heald, S. M.; Liu, C.; Plymale, A. E. Reduction of $\mathrm{TcO}_{4}^{-}$by sediment-associated biogenic $\mathrm{Fe}(\mathrm{II})$. Geochim. Cosmochim. Acta 2004, 68, 3171-3187.

(26) Morris, K.; Livens, F. R.; Charnock, J.; Burke, I.; McBeth, J.; Begg, J.; Boothman, C.; Lloyd, J. R. An X-Ray absorption study of the fate of technetium in reduced and reoxidised sediments and mineral phases. Appl. Geochem. 2008, 23, 603-617.

(27) Peretyazhko, T.; Zachara, J. M.; Heald, S. M.; Jeon, B.-H.; Kukkadapu, R. K.; Liu, C.; Moore, D.; Resch, C. T. Heterogeneous Reduction of $\mathrm{Tc}(\mathrm{VII})$ by $\mathrm{Fe}(\mathrm{II})$ at the Solid-Water Interface. Geochim. Cosmochim. Acta 2009, 72, 1521-1539.

(28) Jaisi, D. P.; Dong, H.; Plymale, A. E.; Fredrickson, J. K.; Zachara, J. M.; Heald, S.; Liu, C. Reduction and long-term immobilization of technetium by $\mathrm{Fe}(\mathrm{II})$ associated with clay mineral nontronite. Chem. Geol. 2009, 264, 127-138.

(29) Marshall, T. A.; Morris, K.; Law, G. T. W.; Mosselmans, J. F. W.; Bots, P.; Parry, S. A.; Shaw, S. Incorporation and retention of ${ }^{99} \mathrm{Tc}$ (IV) in magnetite under high $\mathrm{pH}$ conditions. Environ. Sci. Technol. 2014, 48, 11853-11862.

(30) Liu, Y.; Terry, J.; Jurisson, S. Pertechnetate immobilization with amorphous iron sulfide. Radiochim. Acta 2008, 96, 823-833.

(31) Zachara, J. M.; Heald, S. M.; Jeon, B.-H.; Kukkadapu, R. K.; Liu, C.; McKinley, J. P.; Dohnalkova, A. C.; Moore, D. A. Reduction of Pertechnetate $[\mathrm{Tc}(\mathrm{VII})]$ by Aqueous $\mathrm{Fe}(\mathrm{II})$ and the Nature of Solid Phase Redox Products. Geochim. Cosmochim. Acta 2007, 71, 21372157.

(32) Fredrickson, J.; Zachara, J. M.; Plymale, A. E.; Heald, S. M.; McKinley, J. P. Oxidative dissolution potential of biogenic and abiogenic $\mathrm{TcO}_{2}$ in subsurface sediments. Geochim. Cosmochim. Acta 2009, 73, 2299-2313.

(33) Um, W.; Chang, H.-S.; Icenhower, J. P.; Lukens, W. W.; Serne, R. J.; Qafoku, N. P.; Westsik, J. H., Jr.; Buck, E. C.; Smith, S. C. Immobilization of $99 \mathrm{Tc}$ (VII) by $\mathrm{Fe}(\mathrm{II})$-Goethite and Limited Reoxidation. Environ. Sci. Technol. 2011, 45, 4904-4913.

(34) Fan, D.; Anitori, R. P.; Tebo, B. M.; Tratnyek, P. G.; Lezama Pacheco, J. S.; Kukkadapu, R. K.; Kovarik, L.; Engelhard, M. H.; Bowden, M. E. Oxidative Remobilization of Technetium Sequestered by Sulfide-Transformed Nano Zerovalent Iron. Environ. Sci. Technol. 2014, 48, 7409-7417.

(35) Meyer, R.; Arnold, A. W.; Case, F.; O’Kelley, G. D. Solubilities of $\mathrm{Tc}(\mathrm{IV})$ oxides. Radiochim. Acta 1991, 55, 11-18.

(36) Thorpe, C. L.; Lloyd, J. R.; Law, G. T. W.; Williams, H. A.; Atherton, N.; Cruickshank, J. H.; Morris, K. Retention of 99m Tc at Ultra-trace Levels in Flowing Column Experiments - Insights into Bioreduction and Biomineralization for Remediation at Nuclear Facilities. Geomicrobiol. J. 2016, 33, 199-205.

(37) Burke, I. T.; Boothman, C.; Lloyd, J. R.; McBeth, J.; Mortimer, R. J. G. Reoxidation Behavior of Technetium, Iron, and Sulfur in Estuarine Sediments. Environ. Sci. Technol. 2006, 40, 3529-3535.

(38) Wu, W. M.; Carley, J.; Luo, J.; Ginder-Vogel, M. A.; Cardenas, E.; Leigh, M. B.; Hwang, C. C.; Kelly, S. D.; Ruan, C. M.; Wu, L. Y.; Van Nostrand, J.; Gentry, T.; Lowe, K.; Mehlhorn, T.; Carroll, S.; Luo, W. S.; Fields, M. W.; Gu, B. H.; Watson, D.; Kemner, K. M.; Marsh, T.; Tiedje, J.; Zhou, J. Z.; Fendorf, S.; Kitanidis, P. K.; Jardine, P. M.; Criddle, C. S. In situ bioreduction of uranium (VI) to submicromolar levels and reoxidation by dissolved oxygen. Environ. Sci. Technol. 2007, $41,5716-5723$

(39) Geissler, A.; Law, G. T. W.; Boothman, C.; Morris, K.; Burke, I. T.; Livens, F. R.; Lloyd, J. R. Microbial Communities Associated with the Oxidation of Iron and Technetium in Bioreduced Sediments. Geomicrobiol. J. 2011, 28, 507-518.

(40) Duro, L.; Domènech, C.; Grivé, M.; Roman-Ross, G.; Bruno, J.; Källström, K. Assessment of the evolution of the redox conditions in a low and intermediate level nuclear waste repository (SFR1, Sweden). Appl. Geochem. 2014, 49, 192-205. 
(41) McBeth, J. M.; Lear, G.; Lloyd, J. R.; Livens, F. R.; Morris, K.; Burke, I. T. Technetium Reduction and Reoxidation in Aquifer Sediments. Geomicrobiol. J. 2007, 24, 189-197.

(42) Cui, D.; Eriksen, T. E. Reduction of Pertechnetate in Solution by Heterogeneous Electron Transfer from Fe(II)-Containing Geological Material. Environ. Sci. Technol. 1996, 30, 2263-2269.

(43) Thorpe, C. L.; Morris, K.; Lloyd, J. R.; Denecke, M. A.; Law, K. A.; Dardenne, K.; Boothman, C.; Bots, P.; Law, G. T. W. Neptunium and manganese biocycling in nuclear legacy sediment systems. Appl. Geochem. 2015, 63, 303-309.

(44) Lovley, D. R.; Phillips, E. J. Availability of ferric iron for microbial reduction in bottom sediments of the freshwater tidal potomac river. Appl. Environ. Microbiol. 1986, 52, 751-757.

(45) Viollier, E.; Inglett, P. W.; Hunter, K.; Roychoudhury, A. N.; Van Cappellen, P. The ferrozine method revisited: $\mathrm{Fe}(\mathrm{II}) / \mathrm{Fe}(\mathrm{III})$ determination in natural waters. Appl. Geochem. 2000, 15, 785-790.

(46) Ginn, B.; Meile, C.; Wilmoth, J.; Tang, Y.; Thompson, A. Rapid iron reduction rates are stimulated by high-amplitude redox fluctuations in a tropical forest soil. Environ. Sci. Technol. 2017, 51, $3250-3259$

(47) Harris, S. J.; Mortimer, R. J. G. Determination of Nitrate in Small Water Samples $(100 \mu \mathrm{L})$ by the Cadmium-Copper Reduction Method: A Manual Technique with Application to the Interstitial Waters of Marine Sediments. Int. J. Environ. Anal. Chem. 2002, 82, 369-376.

(48) Brewer, P. G.; Spencer, D. W. Colourimetric determination of $\mathrm{Mn}$ in anoxic waters. Limnol. Oceanogr. 1971, 16, 107-110.

(49) Doornbusch, B.; Bunney, K.; Gan, B. K.; Jones, F.; Gräfe, M. Iron oxide formation from $\mathrm{FeCl}_{2}$ solutions in the presence of uranyl $\left(\mathrm{UO}_{2}{ }^{2+}\right)$ cations and carbonate rich media. Geochim. Cosmochim. Acta 2015, 158, 22-47.

(50) Dreissig, I.; Weiss, S.; Hennig, C.; Bernhard, G.; Zänker, H. Formation of uranium(IV)-silica colloids at near-neutral pH. Geochim. Cosmochim. Acta 2001, 75, 352-367.

(51) Hess, N. J.; Xia, Y. X.; Rai, D.; Conradson, S. D. Thermodynamic Model for the Solubility of $\mathrm{TcO}_{2} \bullet \mathrm{xH}_{(2)} \mathrm{O}_{(\mathrm{am})}$ in the Aqueous $\mathrm{Tc}(\mathrm{IV})-\mathrm{Na}^{+}-\mathrm{Cl}^{-}-\mathrm{H}^{+}-\mathrm{OH}^{-}-\mathrm{H}_{2} \mathrm{O}$ System. J. Solution Chem. 2004, 33, 199-226.

(52) Ravel, B.; Newville, M. ATHENA, ARTEMIS, HEPHAESTUS: data analysis for X-ray absorption spectroscopy using IFEFFIT. J. Synchrotron Radiat. 2005, 12, 537-41.

(53) Downward, L.; Booth, C. H.; Lukens, W. W.; Bridges, F. A variation of the F-test for determining statistical relevance of particular parameters in EXAFS fits. AIP Conf. Proc. 2006, 882, 129-131.

(54) Lane, D. J. 16S/23S rRNA Sequencing. In Nucleic Acid Techniques in Bacterial Systematics; Stackebrandt, E., Goodfellow, M., Eds.; John Wiley and Sons: New York, NY, 1991.

(55) Hamady, M.; Walker, J. J.; Harris, J. K.; Gold, N. J.; Knight, R. Error-correcting barcoded primers for pyrosequencing hundreds of samples in multiplex. Nat. Methods 2008, 5, 235-237.

(56) Williamson, A. J.; Morris, K.; Shaw, S.; Byrne, J. M.; Boothman, C.; Lloyd, J. R. Microbial reduction of $\mathrm{Fe}(\mathrm{III})$ under alkaline conditions relevant to geological disposal. Appl. Environ. Microbiol. 2013, 79, 3320-3326.

(57) Caporaso, J. G.; Kuczynski, J.; Stombaugh, J.; Bittinger, K.; Bushman, F. D.; Costello, E. K.; Fierer, N.; Pena, A. G.; Goodrich, J. K.; Gordon, J. I. QIIME allows analysis of high-throughput community sequencing data. Nat. Methods 2010, 7, 335-336.

(58) Edgar, R. C. Search and Clustering Orders of Magnitude Faster than BLAST. Bioinformatics 2010, 26, 2460-2461.

(59) Clarke, K. R. Non-Parametric Multivariate Analyses of Changes in Community Structure. Aust. J. Ecol. 1993, 18, 117-143.

(60) Peretyazhko, T.; Zachara, J. M.; Heald, S. M.; Kukkadapu, R. K.; Liu, C.; Plymale, A. E.; Resch, C. T. Reduction of Tc(VII) by Fe(II) Sorbed on Al (hydr)oxides. Environ. Sci. Technol. 2008, 42, 54995506.

(61) Heald, S. M.; Krupka, K. M.; Brown, C. F. Incorporation of Pertechnetate and Perrhenate into Corroded Steel Surfaces Studied by
X-Ray Absorption Fine Structure Spectroscopy. Radiochim. Acta 2012, $100,243-253$.

(62) Peretyazhko, T. S.; Zachara, J. M.; Kukkadapu, R. K.; Heald, S. M.; Kutnyakov, I. V.; Resch, C. T.; Arey, B. W.; Wang, C. M.; Kovarik, L.; Phillips, J. L.; Moore, D. Pertechnetate $\left(\mathrm{TcO}_{4}{ }^{-}\right)$Reduction by Reactive Ferrous Iron Forms in Naturally Anoxic, Redox Transition Zone Sediments from the Hanford Site, USA. Geochim. Cosmochim. Acta 2012, 92, 48-66.

(63) Liu, J.; Pearce, C. I.; Qafoku, O.; Arenholz, E.; Heald, S. M.; Rosso, K. M. Tc(VII) Reduction Kinetics by Titanomagnetite $\left(\mathrm{Fe}_{3-\mathrm{x}} \mathrm{Ti}_{\mathrm{x}} \mathrm{O}_{4}\right)$. Geochim. Cosmochim. Acta 2012, 92, 67-81.

(64) Downward, L.; Booth, C. H.; Lukens, W. W.; Bridges, F. A Variation of the F-Test for Determining Statistical Relevance of Particular Parameters in EXAFS Fits. AIP Conf. Proc. 2006, 882, 129131

(65) Zakir, M.; Sekine, T.; Takayama, T.; Kudo, H.; Lin, M.; Katsumura, Y. Technetium (IV) Oxide Colloids and the Precursor Produced by Bremsstrahlung Irradiation of Aqueous Pertechnetate Solution. J. Nucl. Radiochem. Sci. 2005, 6, 243-247.

(66) Plymale, A. E.; Fredrickson, J.; Zachara, J. M.; Dohnalkova, A.; Heald, S. M.; Moore, D.; Kennedy, D. W.; Marshall, M. J.; Wang, C.; Resch, C. T.; Nachimuthu, P. Competitive Reduction of Pertechnetate $\left({ }^{99} \mathrm{TcO}_{4}^{-}\right)$by Dissimilatory Metal Reducing Bacteria and Biogenic Fe(II). Environ. Sci. Technol. 2011, 45, 951-957.

(67) Wildung, R. E.; Gorby, Y. A.; Krupka, K. M.; Hess, N. J.; Li, S. W.; Plymale, A. E.; McKinley, J. P.; Fredrickson, J. Effect of Electron Donor and Solution Chemistry on Products of Dissimilatory Reduction of Technetium by Shewanella Putrefaciens. Appl. Environ. Microbiol. 2000, 66, 2451-2460.

(68) McBeth, J.; Lloyd, J. R.; Law, G. T. W.; Livens, F. R.; Burke, I. T.; Morris, K. Redox Interactions of Technetium with Iron-Bearing Minerals. Mineral. Mag. 2011, 75, 2419-2430.

(69) Coker, V. S.; Bell, A. M. T.; Pearce, C. I.; Patrick, R. A. D.; van der Laan, G.; Lloyd, J. R. Time-resolved synchrotron powder X-ray diffraction study of magnetite formation by the $\mathrm{Fe}(\mathrm{III})$-reducing bacterium Geobacter sulfurreducens. Am. Mineral. 2008, 93, 540-547.

(70) Kersting, A. B.; Efurd, D. W.; Finnegan, D. L.; Rokop, D. J.; Smith, D. K.; Thompson, J. L. Migration of Pu in Groundwaters at the Nevada Test Site. Nature 1999, 397, 56-59.

(71) Walther, C.; Denecke, M. A. Actinide colloids and particles of environmental concern. Chem. Rev. 2013, 113, 995-1015.

(72) Maes, A.; Geraedts, K.; Bruggeman, C.; Vancluysen, A.; Rossberg, A.; Hennig, C. Evidence for the Interaction of Technetium Colloids with Humic Substances by X-ray Absorption Spectroscopy. Environ. Sci. Technol. 2004, 38, 2044-2051.

(73) Gu, B.; Dong, W.; Liang, L.; Wall, N. A. Dissolution of Technetium(IV) Oxide by Natural and Synthetic Organic Ligands under both Reducing and Oxidizing Conditions. Environ. Sci. Technol. 2011, 45, 4771-4777.

(74) Marshall, M. J.; Dohnalkova, A.; Kennedy, D. W.; Plymale, A. E.; Thomas, S. H.; Löffler, F. E.; Sanford, R. A.; Zachara, J. M.; Fredrickson, J.; Beliaev, A. S. Electron Donor-Dependent Radionuclide Reduction and Nanoparticle Formation by Anaeromyxobacter Dehalogenans Strain 2CP-C. Environ. Microbiol. 2009, 11, 534-543.

(75) Thorpe, C. L.; Law, G. T. W.; Lloyd, J. R.; Williams, H. A.; Atherton, N.; Morris, K. Quantifying Technetium and Strontium Bioremediation Potential in Flowing Sediment Columns. Environ. Sci. Technol. 2017, 51, 12104. 